\title{
Controlling Inflation
}

\author{
A speech given by DARRYL R. FRANCIS, President, Federal Reserve Bank \\ of St. Louis, at the 75th Annual Convention of the Kentucky Bankers \\ Association, Louisville, Kentucky, September 15, 1969
}

UR NATION has experienced excessive inflation during most of the period since early 1965 . With the exception of a few months following a restrictive monetary policy in part of 1966 , the rise in the general price level accelerated throughout the period. Since last December consumer prices have increased at a 6 per cent annual rate. Restrictive monetary and fiscal policies have been adopted to curb this excessive demand, but such actions are effective in reducing total demand only after a time lag.

In response to a more restrictive monetary policy, the rate of growth in the stock of money has declined in recent months. Since last December money has risen at a 4 per cent annual rate, compared with a 7 per cent increase during 1968. Passage of the tax bill in mid-1968 resulted in moving the Federal budget to a surplus of about a $\$ 7$ billion annual rate in the first half of 1969 , compared with a deficit of more than a $\$ 12$ billion annual rate from early 1967 to mid-1968.

While to date these restrictive actions have had no apparent impact on prices, we are seeing some results from these actions. The fnancial markets have stopped becoming progressively tighter and the growth rate in total spending has decelerated.

In recent months we have heard repeated suggestion and repeated denial that direct government controls of wages, prices, and credit will be necessary to break the inflationary boom. Secretary of the Treasury David Kennedy, in testimony before the Senate Finance Committee in early July, said he opposed controls, but that procrastination in renewing the tax surcharge would bring on these regulations. ${ }^{1}$ Even earlier, Secretary of Commerce Maurice Stans con-

${ }^{1}$ Business Week, July 12, 1969, p. 102. cluded from letters and conversations that a growing minority of businessmen are so concerned about the pace of inflation that they would favor controls.2

Much to my surprise, my contacts with businessmen in recent months confirm the Commerce Secretary's observation that many are talking favorably of wage and price controls as a solution to the problems of inflation. This line of thinking is direct and avoids theoretical complications. It assumes that, since inflation is a rise in the general price level, direct controls over wages and prices can stabilize prices and thereby prevent the evils of inflation.

The advocates of bureaucratic control of prices assume that such controls are workable alternatives to less expansive monetary policies as a means of halting inflation.

I question the widely assumed "obviousness" of the workability of direct controls of wages, prices, and credit, even under ideal conditions. They are expensive to administer and extremely difficult to enforce. They impair the efficiency of the price system as an allocator of resources and fail to provide an adequate substitute. The arbitrary rationing involved in direct controls is a major infringement on individual liberty and is extremely susceptible to bureaucratic abuses. Direct controls at best are not a solution to inflation but only a partial postponement or masking of price increases in the face of excessive demand.

\section{Experence whith Direc Connols}

Some of you will require only a reminder of the problems of administering the Office of Price Administration (OPA) during World War II. During that

\footnotetext{
${ }^{2}$ Business Week, June 7, 1969, p. 49.
} 
all-out war effort, conditions much more favorable than at present existed for the implementation of direct controls. In the face of the common enemy, virtually all citizens were united and willing to make sacrifices for successful conclusion of the war. In such an emotionally charged atmosphere, broad industry agreements and press releases may have contributed to limitation of price increases in early 1942. During the year, demand for goods and services continued to rise, and production for civilian use declined as a larger per cent of the nation's resources was demanded by the military. Thus upward pressure on prices became more intense.

By late 1942 specific price schedules were necessary. At this time Price Emergency Regulation No. 2 noted that rents were climbing fast, and rent controls were put into effect. ${ }^{3}$ Price Emergency Regulation No. 3 of October 1942 noted that, despite the regulations, wages and farm prices had moved up, forcing continuous amendments and additions to the regulations.

In June 1943, after a hectic 16 months of operating under intense pressure, the OPA was overhauled. The authority for setting prices was passed from the Washington office to the field offices. Numerous advisory committees were appointed, and ration books were issued.

By late 1943 emergence of a black market (selling above OPA price limits) and a shortage of enforcement investigators were noted. The substitution of low-quality goods in the higher-quality price brackets was also apparent. Subsidies to producers became an increasing part of the price control program in the late war years, as set prices were insufficient to provide the necessary incentive for production. Commodities subsidized included coal, lead, copper, tin, petroleum, coffee, and farm products.

The number of workers required to operate and enforce this program was staggering. By $1944,325,000$ price control volunteers, ${ }^{4}$ in addition to 65,000 paid employees, ${ }^{5}$ were being utilized. This was a period when the country was faced with a labor shortage, and most of these people could have worked at productive jobs, thereby contributing to an increase in total output and a lower rate of inflation. In addition

3U.S. Office of Price Administration, Renewal of the Price Control Act, Congress, House Banking and Currency Committee, April 12, 1944.

4lbid., p. 58 .

5U.S. Department of Commerce, Statistical Abstract of the United States, 1946, p. 207. to the number of employees required directly by OPA, the program was a burden to all business establishments. For example, the banking system was handling 5 billion ration coupons per month in 1944 .

By 1946 people were no longer willing to make wartime sacrifices, and much of the wartime price control machinery was bypassed. Breaking the law became extremely profitable. Little respect was shown for a law which banned economic transactions that were permitted and morally acceptable in prewar years.

Both for those who had blind faith in the law and for the profit maximizers, the choice of action was easy - the former to obey the law and the latter to ignore it. For other Americans, the decision of whether or not to obey the law was difficult. Before the regulations were finally revoked, most individuals and businesses participated to various degrees in law breaking, including black marketing, gray markets, tie-in-sales, kickbacks, and upgrading.

Few people were disturbed at the illegal aspect of two or more people making a mutually satisfactory deal at prices above the OPA legal limit. For example, those who wanted a freezer of beef often went directly to a farmer friend and made the purchase at an agreed price. The packing house and retailer, where OPA prices were enforced, were bypassed. Store shelves were often empty and our efficient channels of processing tended to collapse. Nevertheless, those who had good contacts with producers managed to satisfy most of their demands, although at a higher cost through this inefficient means of production and marketing. One OPA official reported that while traveling through Texas he stopped in a rural area where a farmer was slaughtering a steer for illegal sale. The official asked the farmer if he didn't know that the practice was illegal. The farmer replied, "I reckon we ain't heard about that law out here."

Finally, in 1946, after a year of post-war domestic crises which included numerous strikes, food shortages, and a high rate of inflation, most of the provisions for direct controls were ended. Rent controls were the last to go, with some lingering on into the 1950 's and some even to the present day. Owners found it unprofitable to keep rental property in good condition. By the time most rent controls were finally removed, rental property had already become dilapidated. Those World War II rental apartments which continued under controls into the 1950 's now comprise many of our central city slum areas. 


\section{Finction of Price Sustem Inpared}

As an alternative to arbitrary govemment control, the price system is an automatic and impersonal control mechanism. It allocates resources to various types of production according to demand for individual products, and output is determined according to consumers' willingness to pay for goods and services. Income is allocated to individuals and firms according to their contribution to total output. These allocations are made without personal prejudice and with neutrality with respect to political, religious, or social affiliation. In other words, they are made in a highly objective and democratic manner.

I do not contend that the price system is perfect. In the existing market, some business and some labor groups can exercise greater power than others. This and other imperfections, however, are relatively minor compared to problems created by direct controls.

For example, under direct controls, rationing is generally necessary in order to allocate scarce items, and almost all items are scarce under price controls. Allocations of labor and other resources among industries and firms are determined by arbitrary government rules rather than through freedom of choice. Controls which maintain prices and wages below market levels in any industry offer no inducement for the increase in production necessary to alleviate shortages. Arbitrary wage setting is not likely to provide for payments according to individual productivity; consequently, there is little or no inducement to improve one's skill.

Direct government controls, therefore, offer little inducement for the efficient development and use of resources, and contain no automatic mechanism for resource adjustments and the alleviation of shortages or excesses in production. Rather than being an aid to growth and vitality, they lead to economic retardation and reduced national welfare.

\section{Infringemente on Freedom}

Equally as important as the economic shortcomings of direct controls is their useless infringement on freedom. Freedom did not come easily to mankind, but we tend to take it for granted. Yet in most of the periods since man's early history he has been forced to bow in both thought and action to harsh taskmasters. More often than not, his social position, his income, his occupation, and his religion were forced upon him.
Some rays of freedom began to be noticed in much of Western Europe about the time that America was discovered. By the late $1600^{\prime} \mathrm{s}$ freedom of thought and action in the Netherlands was well ahead of that in other European Countries. Similarily, economic progress was most noteworthy there.

The streams of Western Europe's citizens which migrated to the American colonies sought both economic and other freedoms. They came from areas where the state controlled their economic life and the church controlled their thoughts.

Roger Williams led the way toward freedom in the American colonies with a constitution in Rhode Island that provided for relatively little governmental interference with the daily lives of the citizens. This philosophy, which subscribes to a maximum degree of individual freedom, was inherent in the thinking of Jefferson, Adams, Madison, and other founders of this nation.

John Locke, about 300 years ago, postulated a state in which men were free and equal before the law and before each other. His ideal government was one which represented majority rule rather than an exclusive structure for a king or dictator at the top. While Locke recognized that most economic problems were self-adjusting, we must come forward to Adam Smith's day, about 200 years ago, before a harmonious theory was developed showing how an economy works most efficiently under relatively free conditions. To the confusion of most people in his day and of our time, Smith argued that most government efforts designed to improve economic activity and welfare actually were retarding influences. Along with other great philosophers in later years, he pointed to a free and efficient enterprise economy. Added to the freedom to select government officials, this system provides by far the greatest freedom from coercion and want of any system that has so far been devised.

Direct wage and price controls are not compatible with freedom. Instead of workers moving voluntarily from job to job for relatively higher pay, under a direct controls system they must be moved by arbitrary action of government. Under direct controls personal income, living costs, and the very necessities of life are determined arbitrarily by government with an army of enforcers. Such a system contains the ingredients for complete dictatorship at the top and complete subservience at the bottom. It is certainly not compatible with freedom as experienced in America during most of our years since independence. 
Wrge and Price Controls No Solution io Inflation

In addition to the facts that direct wage and price controls are almost impossible to administer, impair important functions of the price system, and are contrary to our ideals of freedom, they do not provide a solution to inflation. During the period from March 1942 to October 1946, in which direct controls were used, the consumer price index rose 6 per cent a year, and there is fairly general agreement that the index understated the actual rate of inflation because of declining quality of products and black market operations. Wages rose at a slightly faster rate than consumer prices.

The stock of money rose at an 18 per cent rate during this period, as the Federal Reserve System sharply increased bank reserves while conducting supporting operations for U.S. government securities. This very expansive monetary policy, coupled with a reduction in output of consumer goods and services, put great upward pressure on prices, and how much wages and prices would have risen in the absence of controls is unknown.

Even if controls hold back reported price and wage increases for the time being, they do not solve the problem of inflation. If excess demand for goods and services has been created, it continues to exist. Direct controls, like a new paint job over a termite infested house, hide the evidence but do nothing to eliminate the cause of the problem. Unless the basic causes of inflation are eliminated, direct controls can only postpone the inevitable price increases until some future date.

\section{Attuck the Cutse of Inflation}

The best solution to the problem of inflation is to eliminate the cause. Inflation occurs because the stock of money (demand deposits and currency in circulation) increases relative to the amount of money that people want to hold, given their level of wealth and income. Starting from a position of stable prices, if additional money is created faster than it is demanded, people will spend more, thereby reducing the proportion of their wealth held in the form of money. When the rate of spending rises faster than production of goods and services, prices rise. Prices continue up until money incomes and wealth are pushed up to the point at which the public wants to hold the increased stock of money. The growth of money is thus the key to inflation, and appropriate monetary control provides the solution to the problem.
The current inflation can be traced to the course of the stock of money. Money grew at an annual rate of 3 per cent from 1961 to early 1965. This rate of growth in the stock of money was accompanied by generally stable prices, moderate economic expansion, and a decline in the rate of unemployment. From the spring of 1965 to the spring of 1966 , the stock of money rose 6 per cent and both spending and inflation accelerated. From the spring of 1966 to the end of the year, the stock of money remained stable, followed shortly by a decline in the rate of inflation.

Rapid monetary expansion was resumed in early 1967, soon followed by acceleration of spending and inflation. From January 1967 to December 1968 the stock of money expanded at a 7 per cent annual rate, and since the second quarter of 1967, the general price index has risen at more than a 4 per cent annual rate. Since last December the stock of money has risen at a more moderate rate, and I look forward, as a result, to a reduction in the growth of total spending and in the rate of inflation during the months ahead.

Throughout most of economic history, inordinate inflations have been limited because the stock of money was tied to a relatively stable quantity of precious metals. That period in history has largely passed, as precious metals are no longer a restraining influence on money creation. Today, the prevention of inordinate inflations depends upon appropriate limitation of the growth in the stock of money by central banks and treasuries.

In the United States, the Federal Reserve System has the responsibility of formulating monetary policy. It is believed by most monetary analysts that the System can control the stock of money through its power to control Federal Reserve credit and bank reserves. When the Federal Reserve System buys government securities, bank reserves are created. With a larger volume of bank reserves, bank expansion can proceed. As new loans and investments are made, the volume of demand deposits, the major component of our stock of money, rises. Sales of govermment securities by the Federal Reserve can reverse the process, reducing the stock of money.

Fiscal deficits are often associated with inflations, primarily because of the method used to finance them. If deficits are accompanied by an inordinate expansion of Federal Reserve credit (as is often the case), excessive money is created. But if the deficit is financed without the creation of new money, it will 
probably have little impact on prices. Proceeds from the sale of government securities will be removed from the private spending stream and the rise in government outlays will be offset by reduced spending in the private sector. In nearly every country experiencing a major inflation, the cause is the creation of new money to finance government activities. We have no evidence, however, that government deficits which are not monetized will lead to inflations.

Some contend that inflations are caused by "wage push" or "administered price actions." The argument is based on the belief that some wages and prices can be arbitrarily increased because of excessive market power. "Wage push" or "cost push" adherents point out that new wage contracts in the steel industry are followed by steel price increases, which are in turn followed by automobile price increases. This series of events, however, does not lead to inflation unless excess demand has been created through monetary expansion. If, through excessive bargaining power, wages are pushed too high in these industries, output will decline in the absence of monetary expansion. Resources will then be released to other industries where prices will fall. Average prices for all goods and services will remain about unchanged once resources are again fully employed. Monetary expansion must accompany "wage push" or "cost push" actions in order for inflation to occur.

\section{Sinmentary}

Our experience during World War II with direct controls on wages and prices was a futile exercise in the economics of admonition and legal restraint. Most price rigidities set up by the OPA caused a breakdown both in our efficient production and marketing channels and in quality standards. Producers who had products which were in great demand, and purchasers who were not satisfied with the rationing process, generally found a way to bypass OPA regulations. Disrespect for the law became the normal pattern of life rather than an aberration. Despite the legal and moral restraints and an army of controllers, prices and wages continued to rise rapidly throughout the war and early postwar years.

If governments were sufficiently strong to set rigid controls on wages and prices, freedom would be greatly reduced. Labor and other resources would be moved from job to job arbitrarily by the government rather than through wage incentives. Much of the managerial function of businesses would shift to the government, and the need for the best managerial talent in the private sector would disappear. Such controls impair the functions of the market system. They eliminate incentive for output increases in areas of rising demand. They are thus conducive to economic retardation rather than progress.

Appropriate monetary policies are the only means that have proved workable throughout history in controlling inflations. When kings and emperors debased their nation's currencies by reducing the precious metal content of money, inflations ensued. Today we debase our currency by excessive creation of paper money and demand deposits. Our means of currency debasement is more sophisticated and less direct than in medieval and ancient ages. Yet, the result is the same - excessive money created relative to production of goods and services lowers its value. The solution requires a proper limitation on the stock of money.

Control over the stock of money in the United States lies chiefly with the Federal Reserve System. Control can be exercised with greater ease when the Federal budget is in balance or surplus, since the Government will not be forced to borrow additional funds in a financial market where credit is restricted by tight monetary policies. Even with stimulative budgetary policies resulting from military or social expenditures, however, the Federal Reserve System can maintain a moderate rate of growth in the stock of money and control over total demand for goods and services through an appropriate rate of money creation.

In contrast to the relatively certain method of controlling inflation through appropriate monetary actions, direct controls on wages and prices do not get at the cause of the problem. To the extent that they retard wage and price increases, they, like an anesthetic, only put the patient to sleep. His malady remains unabated when he is awakened. But in the face of excessive demand for goods and services, the slippages and bypasses, such as black markets, quality distortions, etc., experienced with such controls, create a wide gap between the intent of controls and the actual terms of transactions. This intent to catch all prices and wages in one controls bag, when contrasted to the actual results which have been experienced, reminds me of a short ditty regarding the latest style in bathing suits.

"Mary had a bathing suit, the latest style no doubt, but when she got inside it, she was more than halfway out." 